\title{
Economic Viability and Socio-Environmental Impacts of Solar Home Systems for Off-Grid Rural Electrification in Bangladesh
}

\author{
Swati Anindita Sarker $\left.{ }^{1,2, *} \mathbb{(}\right)$, Shouyang Wang ${ }^{1, *}, \mathrm{~K}$ M Mehedi Adnan ${ }^{3,4} \mathbb{D}_{\text {, }}$ \\ Muhammad Khalid Anser ${ }^{5}$, Zeraibi Ayoub ${ }^{6}$, Thu Hau Ho ${ }^{7}$, Riffat Ara Zannat Tama ${ }^{3}$, \\ Anna Trunina ${ }^{1}\left(\mathbb{D}\right.$ and Md Mahmudul Hoque ${ }^{8}$ \\ 1 School of Economics and Management, University of Chinese Academy of Sciences, Haidian District, \\ Beijing 100190, China; almariann@mails.ucas.ac.cn \\ 2 Department of Agricultural Economics, EXIM Bank Agricultural University Bangladesh, \\ Chapainawabganj 6300, Bangladesh \\ 3 College of Economics and Management, Huazhong Agricultural University, Wuhan 430070, China; \\ mehediadnan@webmail.hzau.edu.cn (K.M.M.A.); raztama@webmail.hzau.edu.cn (R.A.Z.T.) \\ 4 Department of Agricultural Finance \& Banking, Sylhet Agricultural University, Sylhet 3100, Bangladesh \\ 5 School of Public Administration, Xi'an University of Architecture and Technology, Xi'an 710055, China; \\ mkhalidrao@xauat.edu.cn \\ 6 School of Economics and Finance, Xi'an Jiao-Tong University, Xi'an 710049, China; azeraibi@xjtu.edu.cn \\ 7 School of Management, Xi'an Jiao-Tong University, Xi'an 710049, China; hothuhau@stu.xjtu.edu.cn \\ 8 Institute of Development Studies (IDS), University of Sussex, UK BN1 9RH; m.hoque1@ids.ac.uk \\ * Correspondence: aninditaswati@mails.ucas.edu.cn (S.A.S.); sywang@amss.ac.cn (S.W.)
}

Received: 17 December 2019; Accepted: 2 February 2020; Published: 5 February 2020

\begin{abstract}
This study conducted a questionnaire-led survey to explore the financial feasibility and socio-environmental impacts of stand-alone solar home systems (SHS) through stratified random sampling. Based on the above consideration, fifteen cases of studies of various watt peak (Wp) capacities have been investigated to evaluate the economic viability of solar home systems. The results revealed that most of the cases have positive net present value (NPV) and low payback periods, with an internal rate of return (IRR) value ranging from $16 \%$ to $131 \%$, which signifies a high rate of investment exchange. Solar home systems are economically profitable for micro-enterprises and households with low-income generation activities as opposed to the households using it only for lighting. The study found that solar home systems with a capacity above $30 \mathrm{Wp}$ are the most economically viable option, which can also avoid 6.15 to 7.34 tonnes of $\mathrm{CO}_{2}$ emissions during the 20 years of life-cycle, while providing different applications including lighting, recreation, information, health, and economic benefits.
\end{abstract}

Keywords: solar home system; economic viability; financial analysis; environment; Bangladesh

\section{Introduction}

Energy is considered as one of the critical factors of achieving sustainable development. On the other hand, the deficiency of electricity is a significant constraint of economic growth and development of rural areas in underdeveloped countries [1]. Jamil et al. (2016) noted that globally power generation mostly depends on exhausting fossil fuel sources [2]. According to the International Energy Agency (IEA), over 1.1 billion rural people in the developing world have no access to grid electricity [3]. Additionally, many of them continue kerosene usage for the light-generating purpose [4]. The usage of fossil fuel is associated with adverse environmental and health problems because of indoor air 
pollution [5]. Hence, there is a consensus that a shift from traditional energy sources to modern renewable clean energy would relieve the pressure on the environment, improve the living standards of society, and accelerate green economic development that many countries aim to achieve [6].

Renewable energy is extremely important to ensure future energy security, stability, and prosperity. Among different renewable energy sources (solar, bio-fuel, wind, hydro, geo-thermal), solar energy is the most viable option for power generation because of its inexhaustible nature $[7,8]$. Solar energy has the greatest potential of any almost-continual energy sources [9]. The electricity generation from solar energy increases more than 50 thousand megawatts (MW) in several countries including Japan, China, and the United States of America [10,11]. A stand-alone solar home system (SHS) is an effective way to supply uninterrupted electricity, especially in rural off-grid areas [12]. It is silicon made device that converts solar energy into electrical energy through the photoelectric effect, which is comprised of solar panel, inverter, battery charge controller, batteries, power meter, and related devices including light-emitting diode (LED) lights [13]. Furthermore, this system is eco-friendly, manageable and nearly free of maintenances [14]. Nowadays, a stand-alone SHS is considered as the real hope for rural off-grid electrification in developing countries.

Bangladesh, a South Asian developing country, is facing a severe energy crisis. The country is unable to fulfill its electricity demand at an adequate level. Around $88 \%$ of people possess electricity access but $79 \%$ of the grid-connected people suffer load-shedding, and $60 \%$ suffer low-voltage supply problems [3]. Moreover, fossil fuels especially natural gas, are used up to $52.58 \%$ for power generation. It has been projected that the existing natural gas reserve will be depleted sometime in the following decade 2020-2030 [15]. Thus, by using existing resources, Bangladesh has to fulfill the forthcoming electricity requirement of 34,000 megawatts by 2030 [15]. Additionally, the Government of Bangladesh has a vision of providing electricity access to all Bangladeshis by the year $2020[16,17]$, however, the reality seems quite the opposite and that target looks almost impossible to achieve.

Consequently, the environmental effect and the rapid exhaustion of fossil fuel leads to the necessity of discovering alternative energy sources instantaneously to fulfill this requirement [18]. Bangladesh is a subtropical country, situated between $20^{\circ} 34^{\prime}-26^{\circ} 38^{\prime}$ North latitude to $88^{\circ} 01^{\prime}-92^{\circ} 41^{\prime}$ East latitude, and it possesses average daily solar radiation about $4-6.5 \mathrm{kWh} / \mathrm{m}^{2}$ [19]. Because of that, it can use solar panels to produce electricity for rural electrification [20]. The stand-alone solar home systems (SHS) can be the key to the electrification of off-grid rural regions in Bangladesh $[6,21,22]$. For the promotion of SHS in Bangladesh, the Infrastructure Development Company Limited (IDCOL) has been playing a significant role in countrywide program implementation. Approximately 4.13 million SHS have been installed in different remote areas until January 2018 [23], where grid expansion electrification is very expensive and challenging. At present, 56 Partner Organizations (PO) are implementing these programs under the supervision of IDCOL [24]. The consumer can buy an SHS through an installment system with low interest in between three years under the microcredit scheme of the IDCOL program [25].

Another important thing for the adoption of SHS is that consumers usually do not make investment analysis before purchasing the system, as they usually do not possess such types of skills. They want to buy the systems based on observed benefits, perceived experience, and capability of paying installment for credit. Moreover, those consumers who use solar home systems for business purposes may not do any sophisticated analysis like NPV before making investment decisions, but they can anticipate profits. However, the solar home systems would be an appropriate investment decision, including its social, financial and environmental benefits. Nowadays, solar home systems application is being promoted by different government and non-government organizations in rural areas. So, the parent organization must know its economic feasibility and impacts on social life, for the better promotion of the solar home systems to the rural poor people. As per the authors' knowledge, very few studies in Bangladesh focused on the feasibility of SHS and its impacts on social life. Mondal (2010) investigated SHS feasibility in the Gazipur district on 25, 30, and $40 \mathrm{Wp}$ capacity [26] and Halder (2016) looked into SHS feasibility in Sirajganj and Jessore district on 20, 30, and $42 \mathrm{Wp}$ capacity [15]. Moreover, 
Kabir et al. (2017) investigated the social impacts of SHS in the Tangail district [6] and Mondal and Klien (2011) explored the impacts of SHS on social development in Gazipur district [27]. No research has focused on the feasibility of the existing capacity of SHS considering its socio-environmental impacts and barriers-areas which have many implications for making policy guidelines. In this present study, the main objectives are to investigate the economic viability of all the existing capacities of SHS and to find out the most suitable capacity of SHS in Bangladesh by using fundamental financial indicators, and to evaluate the socio-economic and environmental impacts of SHS. These objectives might help to encourage the non-adopter to adopt SHS. Because, nowadays, the adoption of any technology not only depends on its economic performance but also its positive impacts on the environment as well as social life. The observed factors from the study may suggest the suitability of SHS and might be useful for adopting the SHS process, thus contributing toward making a comprehensive energy policy throughout the country as a sustainable basis.

\section{Materials and Methods}

\subsection{Study Area and Data Collection}

Primary data was collected using the questionnaire, interviews, focus group discussion (FGD), and field observations. Three remote villages from Durgapur Upazila under the Netrokona district, namely Kulagura, Boroikandi, and Dhakmara, were chosen (Figure 1), where there is no grid connection but only SHS with traditional power sources. The study area is situated between $25^{\circ} 06^{\prime}$ degrees North latitude and $90^{\circ} 40^{\prime}$ degrees East latitude, which is ideal for solar energy utilization. Around 55\%, $48 \%$, and $41 \%$ of the total number of families use solar home systems respectively in the Kulagura, Boroikandi and Dhakmara villages. A total of 75 cases were interviewed under three categories of use and different capacities of SHS (Table 1). The cases were selected by employing a stratified random sampling process under three major criteria and the availability of respondents. Among them, 45 households and 30 micro-enterprises data were collected. Household data were collected not only from the household heads but also from family members who were present in the interview time and micro-enterprise data collected directly from the owner.

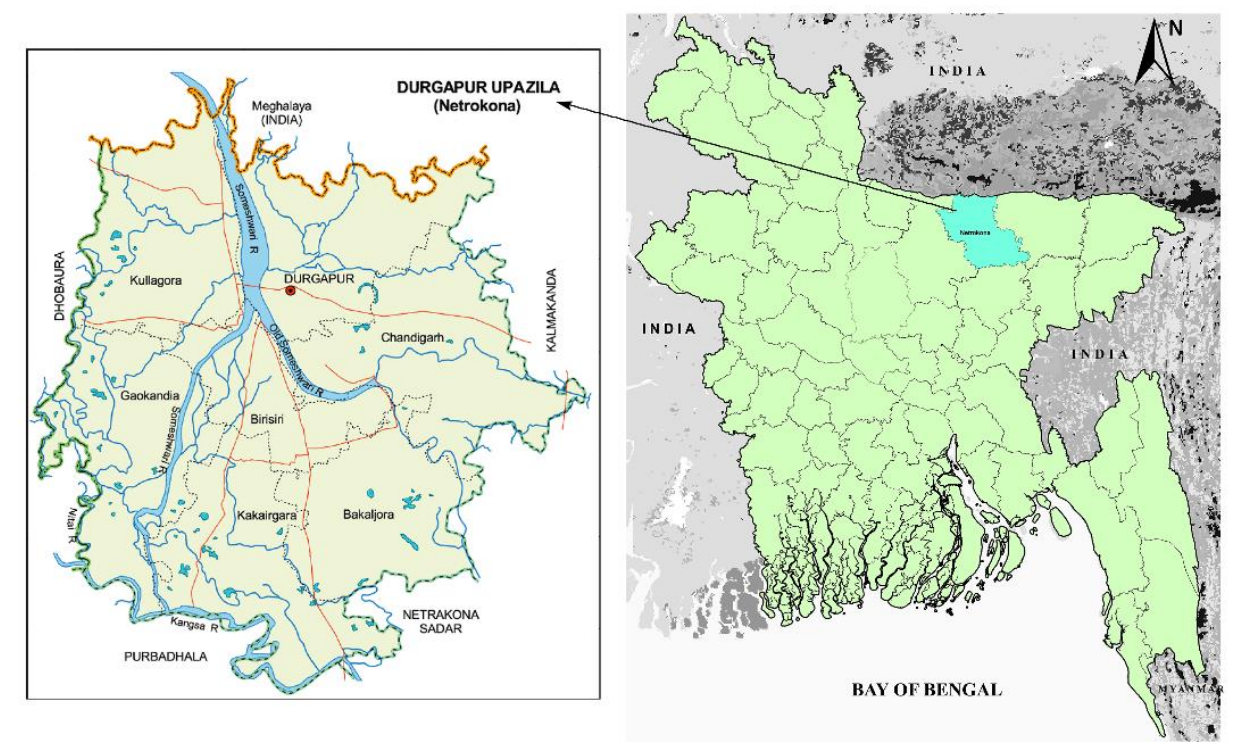

Figure 1. Map of study areas (GIS map). 
Table 1. Distribution of respondents in the study areas.

\begin{tabular}{ccccc}
\hline \multirow{2}{*}{$\begin{array}{c}\text { District and } \\
\text { Upazila Name }\end{array}$} & Village Name & Micro-Enterprise & $\begin{array}{c}\text { Household } \\
\text { Lighting }\end{array}$ & $\begin{array}{c}\text { Household Lighting } \\
\text { with Income } \\
\text { Generation }\end{array}$ \\
\cline { 3 - 5 } & & 10 & 10 & 5 \\
Netrokona district, & Kulagura & 10 & 10 & 5 \\
Durgapur Upazila & Boroikandi & 10 & 10 & 5 \\
\hline Dhakmara & 3 & 30 & 30 & 15 \\
\hline Grand Total & \multicolumn{3}{c}{75} \\
\hline \multicolumn{5}{c}{ Source: Survey data, 2018. }
\end{tabular}

Among 45 households, 30 household users used SHS for only lighting and entertainment purpose, 15 household users for lighting, entertainment, and small income generation purpose. An equal number of respondents were chosen from each village. Three focus group discussions (FGDs) were held in three villages to cross-check the collected data. We have made our best attempt to investigate different kinds of individuals and eliminate any undesirable biases for providing appropriate sample respondents' descriptions. The interviews were documented for more investigation. Secondary data collection was completed mostly thorough reviewing the annual reports of relevant organizations, articles, literature, internet, and informal conversation with focal individuals. Mainly secondary data of different SHS packages were used for assumptions.

\subsection{Sample Selection for Case Studies}

Partner organizations (POs) are working with IDCOL in supplying and supervising SHS in rural areas. Among them, Grameen Shakti (GS), Srizony Bangladesh, and Building Resources Across Communities (BRAC) are the most well-known Non-government organizations (NGOs) that are working in the study areas, and these organizations provide different schemes about installations of SHS. Different respondents use different types and amounts of conventional energy sources before getting the SHS according to their requirements and ability. The SHS capacity varies among different users. Moreover, kerosene consumption also differs between households and micro-enterprise owners. Even the consumption pattern differs between different households. It is challenging to calculate the economic feasibility for total respondents simultaneously under one analytical tool, as it may not reflect the accurate picture. Having some criteria and investigating some respondents as a representative of the total sample for exploring the economic viability of SHS is always better. In the study area, the capacity of the solar home system mostly differs between 20 and $50 \mathrm{Wp}$ including the four to seven working hours for households and small business enterprises. In this study, 15 cases were explored under three major criteria, such as the purpose of use, the capacity of SHS, and the replaced items. The maximum and minimum user belongs to 42 and $20 \mathrm{Wp}$ capacity respectively. For this analysis, only two cases from $20 \mathrm{Wp}$ and four cases from $42 \mathrm{Wp}$ were used, and three cases from other individual capacities.

\subsection{Analytical Procedure for Financial Analysis}

For the economic feasibility analysis, NPV has been conducted to compare its economic benefits with economic costs related to the activity. Hence, all the benefits and costs are determined in monetary value. The financial benefits include the saving from kerosene, replacement costs of lamps, other replacement items (wick or mantle, chimney, hurricane), savings from battery purchase, battery charging, generator bulb charge, bulb cost, cost of charger light, and small income generation due to the extension of working hours excluding the environmental impacts and other long term social benefits. On the contrary, total cost includes the investment cost of the system, repair and maintenance costs, and replacement of components such as the battery, solar inverter, charge controller, LED light, and 
switch. The following assumptions are made for financial analysis as presented in Table 2. The project period is 20 years same as life span of a solar panel, and through this lifetime, solar panels provide the constant power supply. Additionally, we are considering no price escalation and the zero salvage value of the panel after 20 years. Costs and benefits are assumed at present market prices. The increase in equipment cost is not considered for this calculation because the increasing trend of kerosene price can also increase the savings of the owner. System suppliers also provide structure for the panel and switchboard. For the calculation, it has been assumed that there is no need for replacement for these two items. All assumptions are made by using the primary data (interviews and FGD) and secondary sources. Assumptions are almost similar to previous studies [28].

Table 2. Required assumptions for this study.

\begin{tabular}{cc}
\hline Items & Lifespan (Years) \\
\hline \multicolumn{1}{c}{ Solar home systems } \\
\hline Solar panel & 20 \\
Panel/Charge controller & 5 \\
Solar inverter & 15 \\
Battery (lead-acid battery) & 4 \\
Switch & 4 \\
Cable & 5 \\
LED Light & 2 \\
LED light holder & 3 \\
\hline Kerosene lamp system & \\
\hline Hurricane & 5 \\
Chimney & 0.5 \\
Wick or mantle & 0.5 \\
Pressure lamp & 3 \\
\hline
\end{tabular}

Source: Survey and secondary data, 2018.

On the other hand, the financial benefit is the revenue from the system applications. The fundamental principle of appraisal methods is to compare costs against benefits. Although the principle sounds simple, the analysis becomes somewhat tricky because the costs and benefits are spread over a very long period (over 20 years) of time for SHS. The cost of the system has to be made upfront. However, the cost of replacement will be made sometime in the distant future, which makes the estimation difficult. Nevertheless, the more controversial issue is to estimate benefits or cost savings over 20 years. The following three indicators, net present value (NPV), simple payback period, and internal rate of return (IRR), are considered for financial analysis of this study. Financial analysis helps to identify the economic feasibility and mention the investment viability from an economic viewpoint [29]. The calculation of net present value (NPV) has been conducted by considering entire costs and benefits to the year zero. The present market value of SHS components also considered. Three different discount rates $6 \%, 8 \%$, and $12 \%$ are used which signifying the savings account rate, fixed deposit rate, and lending rate of commercial bank respectively. The internal rate of return denotes a discount rate which makes the net current value zero. The payback period is the period that retrieves the primary investment. A short payback period, high net present value, and internal rate of return are essential in ensuring that investment is swiftly regained and risk-free. All economic parameters are computed through these resulting equations.

$$
\begin{gathered}
\text { Paybackperiod }=\frac{\mathrm{I}}{(\mathrm{R}-\mathrm{E})} \\
\mathrm{NPV}=\sum_{1}^{\mathrm{n}} \frac{\left(\mathrm{B}_{\mathrm{n}}-\mathrm{C}_{\mathrm{n}}\right)}{(1+\mathrm{r})^{\mathrm{n}}}
\end{gathered}
$$




$$
\mathrm{IRR}=\mathrm{r}_{1}-\mathrm{NPV}_{1}\left(\frac{\mathrm{r}_{2}-\mathrm{r}_{1}}{\mathrm{NPV}_{2}-\mathrm{NPV}_{1}}\right)
$$

where,

$\mathrm{I}=$ Total Investment

$\mathrm{R}=$ Total Return

$\mathrm{E}=$ Total Expense

$\mathrm{B}_{\mathrm{n}}=$ Total benefit

$\mathrm{C}_{\mathrm{n}}=$ Total cost

$\mathrm{r}=$ Discounting rate

$\mathrm{NPV}_{1}$ and $\mathrm{NPV}_{2}=$ Two different interest rates $\left(\mathrm{NPV}_{1}\right.$ is positive, and $\mathrm{NPV}_{2}$ is negative $)$ $\mathrm{n}=$ Lifespan of a system $(1,2,3 \ldots 20$ year $)$.

\section{Results and Discussions of Financial Analysis}

\subsection{Cost Items}

GS, BRAC, and Srizony Bangladesh are the main investor of SHSs in selected areas. However, more than $70 \%$ of SHSs have already installed by BRAC only. There is numerous financing scheme provided by POs, among the most popular types of scheme to the consumers are as follow:

$>\quad$ Scheme 1: $15 \%$ will be the down payment, and the remaining $85 \%$ will be 36 months' installment payment @ 8\% flat interest rate service charge

$>\quad$ Scheme 2: $25 \%$ will be down the payment, and the remaining $75 \%$ will be 24 months' installment payment @ 6\% flat interest rate service charge

$>\quad$ Scheme 3: 35\% will be down the payment, and the remaining $65 \%$ will be 12 months' installment payment @ 5\% flat interest rate service charge.

Amongst these options, the majority of users choose Scheme 1. Different POs offer different types of packages. The average package details are presented in Table 3.

Table 3. The average package details and cost of stand-alone solar home systems (SHS) in the study area.

\begin{tabular}{|c|c|c|c|}
\hline Capacity (Wp) & Package Details & Back-Up Time & Cost, BDT $(1 \$=80 \mathrm{BDT})$ \\
\hline 20 & $\begin{array}{c}1 \text { Solar Panel-20 W } \\
1 \text { Internal Battery-15 Ah } \\
\text { 1 Solar inverter } \\
\text { 2-3 LED Lights } \\
\text { Electric wiring and Installation }\end{array}$ & $3-4 \mathrm{~h}$ & $16,000-17,000$ \\
\hline 30 & $\begin{array}{c}1 \text { Solar Panel-30W } \\
1 \text { External Battery-30 Ah } \\
1 \text { Solar inverter } \\
\text { 2-3 LED Lights } \\
\text { Electric Wiring and Installation }\end{array}$ & $3-4 \mathrm{~h}$ & $22,000-23,500$ \\
\hline 40 & $\begin{array}{c}1 \text { Solar Panel-40 W } \\
1 \text { External Battery-40 Ah } \\
\text { 1 Solar inverter } \\
\text { 3-4 LED Lights } \\
\text { Electric Wiring and Installation }\end{array}$ & $4-4.5 \mathrm{~h}$ & $28,500-29,500$ \\
\hline
\end{tabular}


Table 3. Cont.

\begin{tabular}{|c|c|c|c|}
\hline Capacity (Wp) & Package Details & Back-Up Time & Cost, BDT (1\$ = 80 BDT $)$ \\
\hline 42 & $\begin{array}{c}1 \text { Solar Panel-40 W } \\
1 \text { External Battery-55 Ah } \\
1 \text { Solar inverter } \\
4-5 \text { LED Lights } \\
1 \text { Solar Stand Fan } \\
\text { Electric Wiring and Installation }\end{array}$ & $4-5 \mathrm{~h}$ & $31,500-32,500$ \\
\hline 50 & $\begin{array}{c}1 \text { Solar Panel-50 W } \\
1 \text { External Battery-55 Ah } \\
\text { 1 Solar inverter } \\
\text { 4-5 LED Lights } \\
\text { 1 Solar Stand Fan } \\
\text { Electric Wiring and Installation }\end{array}$ & $4-5 \mathrm{~h}$ & $36,000-37,000$ \\
\hline
\end{tabular}

Source: Survey data, 2018.

Table 4 represents the prices for the components which might be needed for the change in 20 years' lifetime.

Table 4. Average replacement cost for the items.

\begin{tabular}{cc}
\hline Items & Price in BDT $\mathbf{( 1 \$}=\mathbf{8 0} \mathbf{B D T})$ \\
\hline Panel/Charge controller & 1300 \\
Solar inverter & 5800 \\
Battery (lead-acid battery) & 12,500 \\
Switch & 100 \\
Cable & 250 \\
LED Light & 220 \\
Hurricane & 450 \\
Chimney & 150 \\
Pressure lamp & 2500 \\
Wick or mantle & 50 \\
Charge light & 250 \\
LED light holder & 80 \\
\hline
\end{tabular}

Before using SHS, users used conventional energy sources. In the study areas, the grid charged car battery used to be very popular for running the fan and black and white television. Users also used to rely on $6 \mathrm{~V}$ or $12 \mathrm{~V}$ grid-charged battery for the fan that could be charged with around BDT 125 monthly. Additionally, battery-powered black and white television is pervasive in entertaining and getting news within the selected areas. The average monthly cost of one car battery for running TV is $400 \mathrm{BDT}$ ( $1 \mathrm{USD}=80 \mathrm{BDT}$ approximately). The average monthly kerosene cost of lighting is 280 $\mathrm{BDT} /$ kerosene lamp, while the average consumption is about $4 \mathrm{~L}$ per family (kerosene cost is $70 \mathrm{BDT} / \mathrm{L}$ ). The standard replacement time of one charger light is six months, and the average price is around 250 BDT. Again, for micro-enterprises, the average required amount of kerosene is $12 \mathrm{~L} / \mathrm{month} /$ kerosene pressure lamp. Due to using kerosene pressure lamps, micro-enterprises consume more kerosene.

\subsection{Results and Discussions}

The findings from the financial analysis of different case studies are presented in Table 5 . Table 5 reveals that among 15 case studies, four have negative NPV value and a significant payback period. However, eight cases have positive NPV value and a small payback period. Case 1, 3, 5, and 12 have negative NPV values, and others have positive NPV values. Only case 6 has no payback period with positive NPV and moderate IRR because the owner paid all the investment costs at once and did not take the installment process. 
For cases 1, 3, 5, and 12, the payback periods are 8.81, 40.90, 31.80, and 9.57 years respectively. For these four cases, the most common and important characteristics are, all owners use SHS only for house lighting, and they replace only two kerosene lamps, two kerosene lamps, one kerosene lamp and one battery, and three kerosene lamps respectively. These four cases found no income-generating activities that put them in a financially non-feasible situation. For cases 4, 7, 9, 13 and 15, the payback period is less than three years with positive NPV value and higher IRR. In these five cases, we found that not only lighting purposes but also income generation have been obtained by using SHS. For cases $4,9,13$ and 14, the owners told that they extended working hours by using SHS. Additionally, for cases 7 and 15, the owners use of SHS was not only in-house lighting but also for business purposes. Among these two cases, one maintained a small mobile phone servicing shop by using the SHS and another one increased income via a tailoring business utilizing sewing machines.

Furthermore, cases $8,10,11$, and 14 have small payback periods, positive NPV, but moderate IRR. They also have some income generation activities by using SHS. Only case 2, who uses SHS for house lighting purposes, has positive NPV with a low rate of return and reasonable payback period. He replaced two kerosene lamps and one kerosene pressure lamp with the new SHS, as the maintenance cost of his previous energy sources was too high, especially the kerosene pressure lamp.

Table 5. Summary results of the financial investigation of different case studies.

\begin{tabular}{|c|c|c|c|c|c|c|c|c|}
\hline \multirow{2}{*}{$\begin{array}{l}\text { Case } \\
\text { Studies }\end{array}$} & \multirow{2}{*}{$\begin{array}{l}\text { Capacity } \\
W p\end{array}$} & \multirow{2}{*}{ Purpose of Use } & \multirow{2}{*}{ Replaced Items } & \multirow{2}{*}{$\begin{array}{c}\text { Payback } \\
\text { Periods } \\
\text { (Years) }\end{array}$} & \multicolumn{3}{|c|}{ NPV } & \multirow{2}{*}{ IRR (\%) } \\
\hline & & & & & $6 \%$ & $8 \%$ & $12 \%$ & \\
\hline 1 & 20 & Lighting in house & 2 kerosene lamps & 8.81 & -8373 & -8771 & -9055 & - \\
\hline 2 & 20 & Lighting in house & $\begin{array}{l}2 \text { kerosene lamps } \\
\text { and } 1 \text { kerosene } \\
\text { pressure lamp }\end{array}$ & 5.27 & 9571 & 6334 & 2356 & 15.89 \\
\hline 3 & 30 & Lighting in house & 2 kerosene lamps & 40.90 & -8852 & -9340 & -9685 & - \\
\hline 4 & 30 & Lighting in the shop & $\begin{array}{c}2 \text { kerosene pressure } \\
\text { lamps }\end{array}$ & 1.96 & 40,792 & 35,868 & 26,020 & 75.19 \\
\hline 5 & 30 & Lighting in house & $\begin{array}{c}1 \text { kerosene lamp and } \\
1 \text { battery }\end{array}$ & 31.80 & -7775 & -8122 & -8994 & - \\
\hline 6 & 40 & $\begin{array}{l}\text { Lighting in the } \\
\text { stationary shop, radio, } \\
\text { and phone charge }\end{array}$ & $\begin{array}{l}2 \text { generator bulbs } \\
\text { and } 1 \text { electric } \\
\text { charger light }\end{array}$ & - & 73,187 & 60,161 & 41,688 & 45.99 \\
\hline 7 & 40 & $\begin{array}{l}\text { Lighting in the house } \\
\text { and mobile phone } \\
\text { service, television, and } \\
\text { phone charge }\end{array}$ & $\begin{array}{l}3 \text { generator bulbs, } 1 \\
\text { battery, and } 1 \\
\text { electric charger light }\end{array}$ & 2.27 & 39,650 & 32,698 & 23,028 & 130.95 \\
\hline 8 & 40 & $\begin{array}{l}\text { Lighting in the grocery } \\
\text { shop, television, and } \\
\text { phone charge }\end{array}$ & $\begin{array}{l}2 \text { generator bulb } \\
\text { and } 1 \text { kerosene } \\
\text { pressure lamp }\end{array}$ & 2.80 & 30,549 & 27,666 & 16,427 & 38.90 \\
\hline 9 & 42 & $\begin{array}{l}\text { Lighting in the grocery } \\
\text { shop, television, and } \\
\text { phone charge }\end{array}$ & $\begin{array}{l}2 \text { generator bulb } \\
\text { and } 1 \text { electric } \\
\text { charger light }\end{array}$ & 2.21 & 81,383 & 67,023 & 46,951 & 86.56 \\
\hline 10 & 42 & $\begin{array}{l}\text { Lighting in the house, } \\
\text { operate a sewing } \\
\text { machine, television, and } \\
\text { phone charge }\end{array}$ & $\begin{array}{l}2 \text { generator bulb } \\
\text { and } 2 \text { kerosene } \\
\text { pressure lamps }\end{array}$ & 1.16 & 89,681 & 75,604 & 55,781 & 46.20 \\
\hline 11 & 42 & $\begin{array}{l}\text { Lighting in the phone } \\
\text { service shop, television, } \\
\text { and phone charge }\end{array}$ & $\begin{array}{l}2 \text { generator bulb } \\
\text { and } 1 \text { battery }\end{array}$ & 3.56 & 42,285 & 33,079 & 20,509 & 33.84 \\
\hline 12 & 42 & Lighting in house & 3 kerosene lamps & 9.57 & $-11,580$ & $-12,481$ & $-14,283$ & - \\
\hline 13 & 50 & $\begin{array}{l}\text { Lighting in the grocery } \\
\text { shop, television, and } \\
\text { phone charge }\end{array}$ & $\begin{array}{l}2 \text { generator bulbs, } 1 \\
\text { kerosene pressure } \\
\text { lamp, and } 1 \text { battery }\end{array}$ & 2.27 & 39,650 & 32,698 & 23,028 & 130.90 \\
\hline 14 & 50 & $\begin{array}{l}\text { Lighting in the } \\
\text { stationary shop, and } \\
\text { phone charge }\end{array}$ & $\begin{array}{l}2 \text { generator bulbs } \\
\text { and } 2 \text { electric } \\
\text { charger light }\end{array}$ & 2.44 & 81,050 & 58,730 & 46,349 & 45.70 \\
\hline 15 & 50 & $\begin{array}{c}\text { Lighting in the house, } \\
\text { mobile phone charge, } \\
\text { television, and sewing } \\
\text { machine }\end{array}$ & $\begin{array}{l}3 \text { generator bulbs, } 1 \\
\text { electric charger light, } \\
\text { and } 1 \text { battery }\end{array}$ & 2.21 & 90,430 & 74,475 & 52,170 & 86.56 \\
\hline
\end{tabular}


Additionally, all the positive NPV cases except case 2 have more cash inflows than the initial investment cost at every discount rate level. The positive value of NPV is not the only indicator for identifying the projects' monetary attraction because the discount rate influences it. The IRR value of SHS is very high, ranging from $16 \%$ to $131 \%$, signifying a high rate of return on investment. Additionally, most of the positive NPV cases possess the payback period of fewer than three years, except for case 2 and 11. This shorter payback period confirms the quicker investment recovery hereafter lessen the uncertainty in implementing these programs.

Moreover, it is clear that the capacity of 20 and $30 \mathrm{Wp}$ (Watt-peak) is not a financially viable option for SHS, because most of the cases have negative NPV value or small NPV with low IRR except case 4. It could also be observed that $50 \mathrm{Wp}$ is the best option for rural people with high positive NPV and IRR. Additionally, in most of the cases for SHS, 40 and $42 \mathrm{Wp}$ capacities have positive NPV with high IRR and small payback period except case 12 .

Additionally, this study also found that only the lighting purpose using SHS has negative NPV, expect cases 2 and 4 . These two cases replaced kerosene pressure lamps, and as shown from Table 5, it is found that those who replace the kerosene pressure lamp has positive NPV. So, kerosene pressure lamps played a vital role in the NPV calculation of SHS. Usually, a kerosene pressure lamp consumes much more kerosene than traditional kerosene lamps. Furthermore, from Table 5, it is found that the payback period is a little smaller for the cases of lighting in the house plus income-generating activity, than micro-enterprises where lighting is used as income generation.

Economic analysis is necessary for solar home systems (only for household lighting). Financial analysis is not sufficient for the appreciation of energy investments entirely. Additionally, this analysis is required to consider the social and environmental benefits. Such a financial analysis does not consider the long term effect of lighting facility on child education. Furthermore, it does not take into account the impact of having a television in the house through solar energy, which is otherwise impossible. So, it is very tough to measure the social and environmental benefits. Alternatively, rural households possess the ability and willingness to make an equity investment and take credit from different microfinance institutions for purchasing SHS.

Moreover, society is directly benefited not only through the reduction of kerosene use but also environment protection through carbon dioxide reduction. One kerosene lamp releases $103.2 \mathrm{~g} \mathrm{CO}_{2}$ per hour [30]. One kerosene lamp release $146 \mathrm{~kg} \mathrm{CO}_{2}$ per year considering $4 \mathrm{~h}$ use per night. In Bangladesh, per ton, $\mathrm{CO}_{2}$ reduction cost is approximately $240 \mathrm{BDT}$ (US\$4). It produces an annual savings of 35 $\mathrm{BDT} /$ year and around $700 \mathrm{BDT} / \mathrm{lifetime}$ of SHS for the society. So, it is clear that even consider the environmental benefits negative three cases will not be a financially viable option, because the negative NPV values are such high and environmental benefits from 2-3 kerosene lamps are not sufficient.

According to the results, it can be concluded that the SHS system is financially viable if there have some income-generating purposes rather than only for lighting the house. This result supports another vital issue that the financial viability of SHS depends on the end-use, not on the size of the system. Because improved cost-effectiveness of larger systems is lower than smaller systems [31]. This study also found that most of the owners who have some income-generating activities used more than 30 Wp capacity SHS. Because, in the study areas, it has found that, usually, more than $30 \mathrm{Wp}$ capacity produces sufficient energy which capable of generating extra income rather than only lighting.

\subsection{Comparison with Previous Studies}

The present study found that out of two cases of $20 \mathrm{Wp}$ SHS one has negative NPV and another has positive NPV but a longer payback period with very low IRR, and both cases used SHS only for lighting purpose. This result is similar to Halder and Parvez (2015) findings; they also found negative NPV for $20 \mathrm{Wp}$ SHS only used for lighting [28]. However, P.K. Halder (2016) found $20 \mathrm{Wp}$ SHS has very high NPV, a small payback period, and good IRR, and respondents used SHS for not only lighting purposes but also for small income-generating purposes [15]. The extra income differences here played a vital role for viability. This research also found a similar result for $30 \mathrm{Wp}$ as $20 \mathrm{Wp}$. Out of three 
cases, only one has positive NPV and a small payback period, which is used for micro-enterprises as an income-generating purpose. This result supports the result of other studies [26]. In this study, seven cases are analyzed for $40 \mathrm{Wp}$ and $42 \mathrm{Wp}$ SHS. Only one case has a negative NPV (42 Wp), which is used for only lighting purposes. Others are used either for extra income generation or recreational and technology used purposes. All positive cases replaced many traditional energy sources whose maintenance is expensive. These results are also supported by other researchers $[15,26]$. The present study found moderately similar NPV and payback periods, but the high range of IRR compared to previous studies. In those schemes that included income-generating activities, the IRR values were found to be higher in the present study $(39 \%-130 \%)$ than in previous studies $[15,26]$.

\section{Impacts of Solar Home Systems}

\subsection{Environmental Impacts}

Before getting the SHS, the respondents of the selected area used various kinds of traditional energy sources, especially kerosene. Generally, kerosene releases $\mathrm{CO}_{2}$ extensively while burning that is assessed as approximately $2.5 \mathrm{~kg}$ per liter of kerosene [32]. In the study areas, the standard uses of kerosene are 4 and $12 \mathrm{~L} /$ month by one kerosene lamp and one kerosene pressure lamp respectively. Thus, in a year $120(2.5 \times 4 \times 12)$ and $360 \mathrm{~kg}(2.5 \times 12 \times 12)$ of $\mathrm{CO}_{2}$ is released by one kerosene lamp and one kerosene pressure lamp respectively, which has been avoided by using SHS. It is projected that a single kerosene lamp releases about $103.2 \mathrm{~g} \mathrm{CO}_{2}$ in an hour [30]. Moreover, SHS can be useful in grid connected areas to avoid $\mathrm{CO}_{2}$ emission. It is possible to calculate the avoided amount of $\mathrm{CO}_{2}$ emission through the following equation mentioned here. In the study areas, households possess 4-6 LED lights, 2-4 alternating current (AC) fans, 1 television (black and white). Operating times for the LED lights differs from $8-10 \mathrm{~h} /$ day, a fan is $8-13 \mathrm{~h} /$ day, and TV is $2-7 \mathrm{~h} /$ day. The required power for every LED light is $10-13 \mathrm{~W}$, an AC fan is $70-100 \mathrm{~W}$, and the TV is $100-120 \mathrm{~W}$. For the production of per MWh of energy, the weighted average grid emission factor for traditional fuel-based power plants in Bangladesh is around 0.67 tonnes of $\mathrm{CO}_{2}$ [33]. Based on this, the total avoided $\mathrm{CO}_{2}$ emissions for the adoption of SHS under 20 years' lifecycle can easily be calculated. For this, the following equation is used:

$$
\mathrm{CO}_{2}(\text { Emission })=\frac{E_{d} \times 0.67 \times 365 \times 20}{1000}(t / m w h)
$$

Here, $E_{d}=$ The energy demand per day. $E_{\mathrm{d}}$ can be calculated by

$$
E_{d}=\frac{\sum_{k=1}^{N} A_{k} P_{k} Q_{k}}{1000}(k w h)
$$

where, $k=$ Index of each category of load (fan, lights, TV, radio.); $A_{k}=$ Number of hours' $k^{\text {th }}$ device category used/day; $P_{k}=$ Power rating of $k^{\text {th }}$ device category; $Q_{k}=$ Number of devices of $k^{\text {th }}$ category. Based on households' average usage of different electronic devices and capacity of the SHS, it has estimated that a stand-alone SHS can avoid around 6.15 to 7.34 tonnes of $\mathrm{CO}_{2}$ emissions. This result is similar to Mukherjee and Ghosh, who also found that a solar home system reduces about 6 tonnes of $\mathrm{CO}_{2}$ over a twenty years' life-cycle [34]. Thus, there is not only monetary benefit, but it has also been found that the existing grid electricity generated from fossil fuel produces higher $\mathrm{CO}_{2}$ emissions, while the solar home system can reduce the energy demand with a lower $\mathrm{CO}_{2}$ emission. Moreover, this technology reduces the usage of the kerosene lamp and small diesel generator, which has a direct positive impact on rural local air $[35,36]$ as an SHS generates electricity with no discharge of carbon monoxide $(\mathrm{CO})$, nitric oxides $\left(\mathrm{NO}_{\mathrm{x}}\right)$, or sulfur dioxide $\left(\mathrm{SO}_{2}\right)$, which negatively affect air quality [37].

\subsection{Socio-Economic Impacts}

The SHS possesses both direct and indirect influences on the users, including some effects everlasting in behavior. The use of SHS improves the overall living quality of the user. According 
to GOGLA (neutral, independent, not-for-profit industry association), for nearly three-quarters of customers, the main reason to purchase a SHS is to gain reliable access to light $(74 \%)$, with the second most common driver being the ability to charge mobile phones $(42 \%)$-both are foundational services provided by all sizes of solar home systems [38]. Figure 2 enlisted the positive impacts of SHS on living standards in the considered areas. Several socio-economic benefits are discussed below:

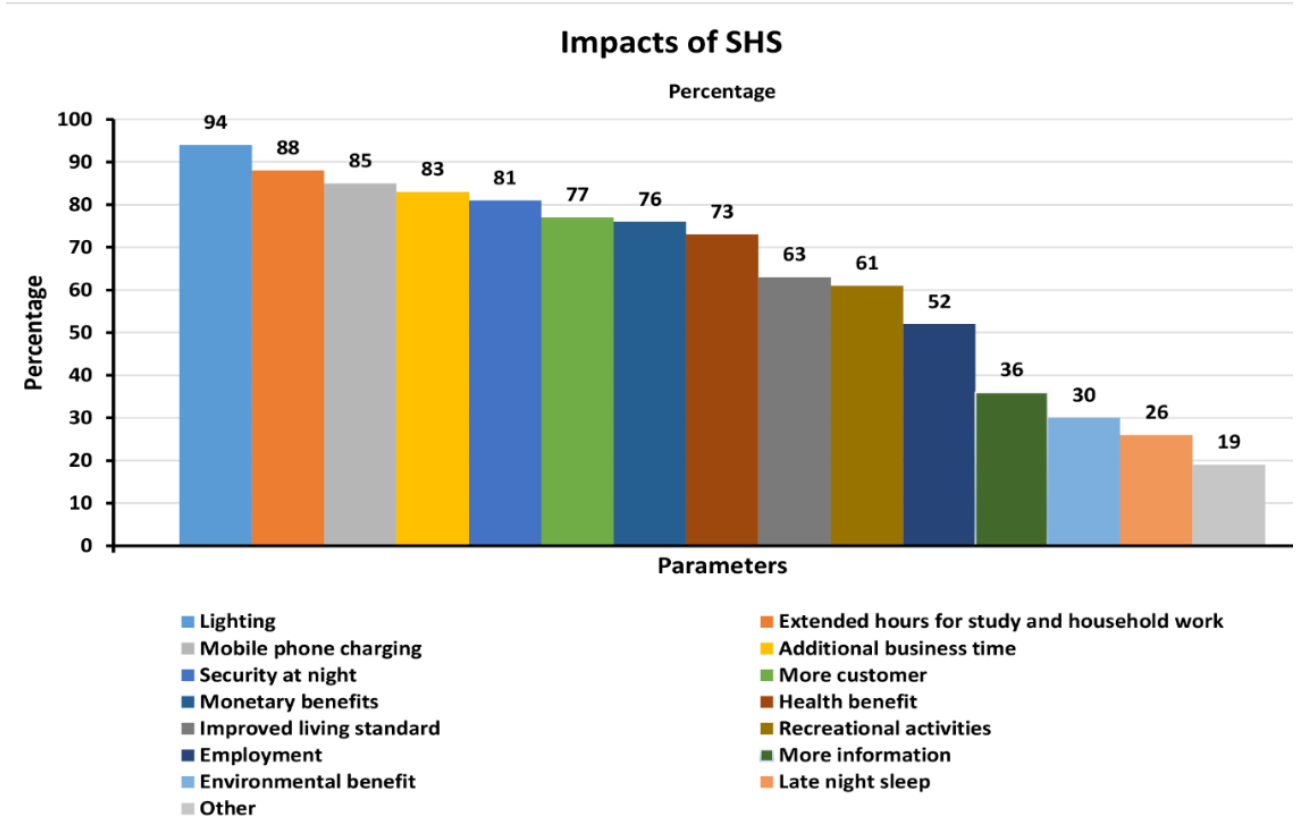

Figure 2. Socio-economic impacts of solar home systems.

\subsubsection{Lighting Impacts}

Lighting is the main application of SHS, and all packages under an SHS include Light-Emitting Diodes (LED) bulbs. LED bulbs are power-efficient and easy to use. Additionally, it provides a brighter light than a traditional kerosene lamp. Around $94 \%$ of rural SHS users accepted it for this facility. This facility offers rural families, especially women, extra time to do household work as well as allowing them to work at night, and students are allowed more time to study and improve their educational qualities [6], as almost $88 \%$ of users respond that an SHS provides extra time to do more work and study. This result is similar to the previous study by Halder and Parvez [28]. Nearly every woman is satisfied with the SHS because it eliminates the dependency of finishing household work before night.

Moreover, before SHS adoption, they sleep early, but now they sleep late. The SHS provides rural inhabitants some extra time to spend with family and friends. Additionally, it plays a significant role in improving the security of the household. Above $80 \%$ of respondents agree with the improvement of social safety and security and reducing the number of criminal activities in the respective areas after the installation of SHS.

\subsubsection{Recreational and Information Impacts}

Solar electricity increases the use of television, radio, and mobile phones with internet facilities, any of which can be used as a medium of entertainment as well as a collection of valuable information about the latest agricultural production process, market information, and credit facilities which develop the farm production system with income up-gradation [39]. A similar result was also found by Kabir et al., who confirmed that, since purchasing the solar home system, $90 \%$ of households use solar electricity for phone charging and they can use their phones more and with $30 \%$ of TV users reporting they watch it every day [6]. Rural people usually gather in the tea-stalls to watch different programs, movies and matches on the television which helps them in relaxing after hard-working 
times. Nowadays, government organizations and NGOs disseminate health, nutrition, family planning issues, and environmental development information through television, radio, and mobile phones. Using this type of technology through SHS plays a vital role in rural development.

\subsubsection{Economic Impacts}

The SHS is considered an economically viable technology for rural people in Bangladesh. More than two-thirds of respondents $(76 \%)$ agree that SHS increases the monetary income. Half of the respondents $(52 \%)$ believe that this technology increases the probability of employment via new income-generating activities. Around $83 \%$ of microenterprise respondents inform that SHS extended the business time up to $4 \mathrm{~h}$, and it brings more customers as well as more income. Similar results were found in earlier research $[6,27,40]$. Both money and time savings from SHS, as well as the better lighting facility, increase the involvement in commercial works, such as sewing machines, small shop related businesses, and small cottage businesses.

\subsubsection{Health Impacts}

The solar home systems replace the kerosene lamp, which has a bad side effect on air, fires, and blasts $[37,41]$. In comparison with a kerosene lamp, solar lighting systems are free from harmful releases with brighter lights to comfort the eyes. Almost two-thirds of respondents believe that SHS has health benefits. It protects the eyes from low-quality light of kerosene lamps. Additionally, it increases indoor air quality to prevent some other health problems, such as lung infection, asthma, and cancer [42]. $63 \%$ of respondents agree that SHS has improved the quality of life.

\section{Constraints of Solar Home Systems}

The majority of solar home systems users are pleased with SHS. However, lack of technological proficiency and poor after-sales facility are the major limitations, as stated by respondents.

\subsection{Disposal of Battery}

Solar energy is a secure and sustainable source of renewable energy. During electricity production by using solar energy, there is a small chance of environmental pollution. Moreover, only battery associated waste harms the environment. Usually, the life span of a battery is around five years. After every five years, it needs to be replaced. Therefore each year, a solar home system needs a lot of batteries. Abandoned battery disposal generates the risk of soil and water contamination. In this investigation, respondents are asked to explain the old battery disposal management for identifying battery disposal management. Nearly $42 \%$ of households do not have any knowledge about the disposal of old batteries. More than $57 \%$ of respondents stated that this is dangerous. That is why they usually sell it in the local market, and about $11 \%$ of respondents stated that after finishing its life span, they discard it. However, the respondents only know that they will get a free new battery if the battery becomes a failure before finishing its warranty period (5 years). Therefore, for rural people, it is very alarming because they do not have enough knowledge about battery disposal management. A battery recycling policy was first formed in 2013 in Bangladesh, while government-enforced retailers for recycling batteries. The parent organizations gather old batteries from households and return them to the manufacturer company for recycling. However, the battery collection from rural areas is a challenging task and also the implementation rate of this policy is poor. Even POs do not visit the solar home systems after their installment collection. Due to the lack of awareness of the consumers and POs, a lot of old batteries can generate another environmental hazard, and thus act as a setback to sustainable development. 


\subsection{Lack of Technical Support}

Solar home systems replace the kerosene lamp, which has a side effect on poisoning; almost $80 \%$ of users complain that awaiting the time for fixing an SHS difficulty is too large, and it takes off a day or two or even more. Additionally, the respondents said that the frequency of power failure due to a technical problem is around three times a year. Insufficient technical persons and technical knowledge decrease the chance of SHS adoption.

\subsection{High Initial Investment and Repair Cost}

The initial down payment investment cost is around 3500-5000 BDT, which can become a huge investment to poor farmers. Furthermore, the costs of battery replacement after six or seven years denoted a crucial financial problem to the users. The cost of an SHS is identified as one of the main difficulties for its practice. Numerous users $(40 \%)$ specified that they confronted complications at initial down-payments and monthly payments. A notable limitation of the poor users is that the smallest monthly installment seems to be a comparatively immense amount for the poor rural peoples, while kerosene can be bought easily in lesser amounts at low prices day-to-day, and if needed, through credit.

\subsection{Technical and Maintenance Problems}

Around $12 \%$ of considered solar panels are not generating electricity up to its optimum capacity because of several issues, for example, bad quality of silicon cell, shaded by trees. Furthermore, solar panels slowly face damage by UV rays, rains, mud, temperatures variations, storm, and winds. In addition, it has been observed that a few users (15\%) do not clean the panel surface frequently. Consequently, deep layers of dirt gather on the panel surface, instigating a fall in power production. Approximately $25 \%$ of the respondents made complaints that the battery charge is inadequate to fulfill their necessities. Around 19\% of the respondents observed that the battery produces over-heating in the using time. Approximately $23 \%$ of users faced darkness or low brightness of LED lights. Additionally, it is not possible to charge the battery fully throughout the rainy season or foggy weather conditions. Thus, the user is required to consume carefully. Moreover, several SHS users just discarded the worn-out or defective SHS equipment's, which is a matter of leading environmental concerns.

\section{Conclusions}

Energy scarcity, depleting natural gas dependency, and the high production-transmission cost of national grid connection force people to search for an alternative for rural off-grid electrification. Stand-alone SHS is attaining a great momentum and becoming the most feasible alternative way for this situation. Thus, the objective of this study is to provide analyses on the financial viability and the socio-environmental impacts of SHS in rural areas of Bangladesh. In light of that objective, 15 case studies are completed to investigate the economic viability. The results mostly show positive NPV and low payback period and the IRR values ranging from $16 \%$ to $131 \%$, signifying a high rate of return on investment. The study also found that solar home systems with a capacity above $30 \mathrm{Wp}$ are the most economically viable option and an SHS can reduce around 6.15 to 7.34 tonnes of $\mathrm{CO}_{2}$ emissions during its life-cycle. Based on these results, it can be concluded that SHS is economically and socio-environmentally viable option for small business enterprises and households with low-income generation activities rather than the households that use it for only lighting purposes. The most notable barriers to SHS adoption are high investment costs and insufficient technical knowledge. However, this research can be useful for policymakers to introduce more convenient and accessible, user-friendly SHS policies for off-grid rural electrification. Government and non-government organizations can introduce household fuel expenditure based on monthly payment systems and attractive installation packages for the mass adoption of SHS. They can also offer different training facilities through advanced extension services for the user of SHS. Moreover, high-quality materials and components with the standard after-sales service may be used to improve the popularity of this technology, which can help 
to address the problem of the current energy crisis and boost up the rural revitalization process as a sustainable basis.

Author Contributions: Conceptualization, S.A.S. and K.M.M.A.; methodology, S.A.S., K.M.M.A., and T.H.H.; software, K.M.M.A., M.K.A., and Z.A.; validation, S.A.S. and S.W.; formal analysis, S.A.S., K.M.M.A., and M.K.A.; investigation, S.A.S., K.M.M.A., and Z.A.; resources, S.W.; data curation, S.A.S., K.M.M.A., and R.A.Z.T.; writing-original draft preparation, S.A.S. and K.M.M.A.; writing-review and editing, M.K.A., Z.A., T.H.H., R.A.Z.T., A.T., and M.M.H.; supervision, S.W.; funding acquisition, S.W. All authors have read and agreed to the published version of the manuscript.

Funding: This research was supported by the "CAS-TWAS President's Fellowship" and The National Nature Science Foundation of China under Grant numbers 71390330 and 71390331.

Conflicts of Interest: The author declares no conflict of interest.

\section{References}

1. Kaygusuz, K. Energy services and energy poverty for sustainable rural development. Renew. Sustain. Energy Rev. 2011, 15, 936-947. [CrossRef]

2. Jamil, M.; Ahmad, F.; Jeon, Y. Renewable energy technologies adopted by the UAE: Prospects and challenges-A comprehensive overview. Renew. Sustain. Energy Rev. 2016, 55, 1181-1194. [CrossRef]

3. Daly, H. Energy Access of Bangladesh; International Energy Agency: Paris, France, 2018.

4. Markandya, A.; Wilkinson, P. Electricity generation and health. Lancet 2007, 370, 979-990. [CrossRef]

5. Guta, D.D. Determinants of household adoption of solar energy technology in rural Ethiopia. J. Clean. Prod. 2018, 204, 193-204. [CrossRef]

6. Kabir, E.; Kim, K.-H.; Szulejko, J. Social impacts of solar home systems in rural areas: A case study in bangladesh. Energies 2017, 10, 1615. [CrossRef]

7. Ellabban, O.; Abu-Rub, H.; Blaabjerg, F. Renewable energy resources: Current status, future prospects and their enabling technology. Renew. Sustain. Energy Rev. 2014, 39, 748-764. [CrossRef]

8. Sahu, B.K. A study on global solar PV energy developments and policies with special focus on the top ten solar PV power producing countries. Renew. Sustain. Energy Rev. 2015, 43, 621-634. [CrossRef]

9. Vasseur, V.; Kemp, R. The adoption of PV in the Netherlands: A statistical analysis of adoption factors. Renew. Sustain. Energy Rev. 2015, 41, 483-494. [CrossRef]

10. Dinçer, F. Overview of the photovoltaic technology status and perspective in Turkey. Renew. Sustain. Energy Rev. 2011, 15, 3768-3779. [CrossRef]

11. Dincer, F. The analysis on photovoltaic electricity generation status, potential and policies of the leading countries in solar energy. Renew. Sustain. Energy Rev. 2011, 15, 713-720. [CrossRef]

12. Stojanovski, O.; Thurber, M.; Wolak, F. Rural energy access through solar home systems: Use patterns and opportunities for improvement. Energy Sustain. Dev. 2017, 37, 33-50. [CrossRef]

13. Leonzio, G. Solar systems integrated with absorption heat pumps and thermal energy storages: State of art. Renew. Sustain. Energy Rev. 2017, 70, 492-505. [CrossRef]

14. El Chaar, L.; El Zein, N. Review of photovoltaic technologies. Renew. Sustain. Energy Rev. 2011, 15, $2165-2175$. [CrossRef]

15. Halder, P.K. Potential and economic feasibility of solar home systems implementation in Bangladesh. Renew. Sustain. Energy Rev. 2016, 65, 568-576. [CrossRef]

16. Taheruzzaman, M.; Janik, P. Electric Energy Access in Bangladesh. Trans. Environ. Electr. Eng. 2016, 1, 6-17. [CrossRef]

17. Division, P. Vision Statement: To Provide Access to Affordable and Reliable Electricity to All by the Year 2020; Ministry of Energy and Mineral Resources, Government of the People's Republic of Bangladesh, 2016.

18. Asif, M.; Barua, D. Salient features of the Grameen Shakti renewable energy program. Renew. Sustain. Energy Rev. 2011, 15, 5063-5067. [CrossRef]

19. Chowdhury, M.N.M.; Uddin, S.; Saleh, S. Present scenario of renewable and non-renewable resources in Bangladesh: A compact analysis. Int. J. Sustain. Green Energy 2014, 3, 164-178. [CrossRef]

20. Tsoutsos, T.; Frantzeskaki, N.; Gekas, V. Environmental impacts from the solar energy technologies. Energy Policy 2005, 33, 289-296. [CrossRef] 
21. Amin, S. The Macroeconomics of Energy Price Shocks and Electricity Market Reforms: The Case of Bangladesh. Ph.D. Thesis, Durham University, Durham, UK, 2015.

22. Rahman, S.M.; Ahmad, M.M. Solar Home System (SHS) in rural Bangladesh: Ornamentation or fact of development? Energy Policy 2013, 63, 348-354. [CrossRef]

23. Kabir, E.; Kumar, P.; Kumar, S.; Adelodun, A.A.; Kim, K.-H. Solar energy: Potential and future prospects. Renew. Sustain. Energy Rev. 2018, 82, 894-900. [CrossRef]

24. Kurata, M.; Matsui, N.; Ikemoto, Y.; Tsuboi, H. Do determinants of adopting solar home systems differ between households and micro-enterprises? Evidence from rural Bangladesh. Renew. Energy 2018, 129, 309-316. [CrossRef]

25. Khandker, S.R.; Samad, H.A.; Sadeque, Z.K.; Asaduzzaman, M.; Yunus, M.; Haque, A.E. Surge in Solar-Powered Homes: Experience in Off-Grid Rural Bangladesh; The World Bank: Washington, DC, USA, 2014.

26. Mondal, M.A.H. Economic viability of solar home systems: Case study of Bangladesh. Renew. Energy 2010, 35, 1125-1129. [CrossRef]

27. Mondal, A.H.; Klein, D. Impacts of solar home systems on social development in rural Bangladesh. Energy Sustain. Dev. 2011, 15, 17-20. [CrossRef]

28. Halder, P.K.; Parvez, M.S. Financial Analyses and Social Impact of Solar Home Systems in Bangladesh: A case Study. Int. J. Renew. Energy Res. (IJRER) 2015, 5, 398-403.

29. Tomosk, S.; Wright, D.; Hinzer, K.; Haysom, J.E. Analysis of present and future financial viability of high-concentrating photovoltaic projects. In High Concentrator PhotoVoltaics; Springer International Publishing: Cham, Switzerland, 2015; pp. 377-400.

30. Sohel, S.; Jaman, R. Economic sustainability of Solar Home System in rural Bangladesh. In Proceedings of the International Conference on Renewable Energy for Rural Development, Dhaka, Bangladesh, 11-12 July 2002; p. 266.

31. Bruch, M.; Müller, M. Calculation of the Cost-Effectiveness of a PV Battery System. Energy Procedia 2014, 46, 262-270. [CrossRef]

32. Schultz, C.; Platonova, I.; Doluweera, G.; Irvine-Halliday, D. Why the developing world is the perfect market place for solid state lighting. In Proceedings of the Eighth International Conference on Solid State Lighting, San Diego, CA, USA, 11-13 August 2008; p. 705802.

33. Ministry of Environment and Forest. Government of People's Republic of Bangladesh: 2019.

34. Mukherjee, S.; Ghosh, P. Estimation of carbon credit and direct carbon footprint by solar photovoltaic cells in West Bengal, India. Int. J. Low-Carbon Technol. 2012, 9, 52-55. [CrossRef]

35. Komatsu, S.; Kaneko, S.; Ghosh, P.P. Are micro-benefits negligible? The implications of the rapid expansion of Solar Home Systems (SHS) in rural Bangladesh for sustainable development. Energy Policy 2011, 39, 4022-4031. [CrossRef]

36. Komatsu, S.; Kaneko, S.; Shrestha, R.M.; Ghosh, P.P. Nonincome factors behind the purchase decisions of solar home systems in rural Bangladesh. Energy Sustain. Dev. 2011, 15, 284-292. [CrossRef]

37. Epstein, M.; Bates, M.; Arora, N.; Balakrishnan, K.; Jack, D.; Smith, K. Household fuels, low birth weight, and neonatal death in India: The separate impacts of biomass, kerosene, and coal. Int. J. Hyg. Environ. Health 2013, 216, 523-532. [CrossRef]

38. GOGLA. Powering Opportunity The Economic Impact of Off-Grid Solar; Neutral, Independent, Not-for-Profit Industry Association: The Netherlands, 2018.

39. Mala, K.; Schläpfer, A.; Pryor, T. Better or worse? The role of solar photovoltaic (PV) systems in sustainable development: Case studies of remote atoll communities in Kiribati. Renew. Energy 2009, 34, 358-361. [CrossRef]

40. Wijayatunga, P.D.C.; Attalage, R.A. Socio-economic impact of solar home systems in rural Sri Lanka: A case-study. Energy Sustain. Dev. 2005, 9, 5-9. [CrossRef]

41. Lam, N.L.; Smith, K.R.; Gauthier, A.; Bates, M.N. Kerosene: A review of household uses and their hazards in low-and middle-income countries. J. Toxicol. Environ. Health Part B 2012, 15, 396-432. [CrossRef] [PubMed]

42. Nandasena, S.; Wickremasinghe, A.R.; Sathiakumar, N. Indoor air pollution and respiratory health of children in the developing world. World J. Clin. Pediatr. 2013, 2, 6. [CrossRef]

(C) 2020 by the authors. Licensee MDPI, Basel, Switzerland. This article is an open access article distributed under the terms and conditions of the Creative Commons Attribution (CC BY) license (http://creativecommons.org/licenses/by/4.0/). 